\title{
Paradox and Transcendence of Diasporic Immigrant Literature: Taking Middlesex as an Example
}

\author{
MuJia \\ School of Foreign Languages, JiShou University, ZhangJiajie, Hunan, China \\ mujiakuaile@163.com
}

\begin{abstract}
Diasporic immigrant literature as a political thought is not equal to "multiculturalism", which is not a political antidote for coordinating minorities and majorities. Taking Jeffrey Eugendies's Middlesex as an example, diasporic immigrant culture is full of paradoxes, among them there are "identity politics" and "politics of difference", which leads to the situation that the mainstream culture can't accommodate the immigrant culture because of the differences between cultures and different recognition of identity. Therefore, the best and possible way to solve this problem is cosmopolitanism.

Index Terms - diasporic immigrant literature, culture identity, Middlesex

Middlesex, which is the second novel of Jeffrey Kent Eugenides, is an informative and imaginative novel, including family secrets and many sensitive social issues, such as, race riots, war, immigrants and hermaphrodite, combining the romantic Greek mythology with the reality of American life ingeniously. This novel was set in the horizon of diaspora, adopting related theories on narrative discourse and culture identity, on the other hand, it depends on the Greek family of the novel in diaspora as the object to explore the efforts the diaspora make in pursuit of compromised identities in terms of ethnicity, religion, politics and religion.
\end{abstract}

\section{Diaspora and Diasporic Immigrant Literature}

Diaspora is a Greek word, which is originated from diaspeirein, " dia-"means "apart", "speirein" means " to sow, scatter". In the past, "diaspora" had a very specific meaning. It referred to the Jewish experience of exile from their historic homeland and their dispersion throughout many lands, signifying as well the oppression and moral degradation implied by that dispersion. The New Shorter Oxford English Dictionary's definition of "Diaspora" takes its meaning primarily from the Jewish experience as well; "The dispersion of Jews among the Gentile nations; all those Jews who live outside the biblical land of Israel". Diasporas, the voluntary or forcible movement of peoples from their homelands into new regions, is a central historical fact of colonization. Colonialism itself was a radically diasporic movement, involving the temporary or permanent dispersion and settlement of Europeans over the entire world. The widespread effects of these migrations continue on a global scale. The descendants of the diasporic movements generated by colonialism have developed their own distinctive cultures which both preserve and often extend and develop their originary cultures. The definition of diaspora has moved away from an idea Jewish type. William Safran has outlined several features of the diaspora that include other kinds of diaspora such as the Indian and Chinese.[1] With the time go on, modern societies which are characterized by a conviction in progress, universality and stability are confronted with emerging postmodernism dominated by doubt, fragmentation, and the end of gran narratives of truth, racial mixing and fluid identities. These are foundations of the appearance of postmodernist thought in the 2980s. In this setting, a view of "diaspora" developed that was totally different from both the open and the categorical definitions above. These definitions lay an emphasis on the point of departure and maintenance of an identity despite of dispersion, whose archetype is the Jewish model. Postmodernism gives place to paradoxical identity, he noncenter and hybridity. To some extent, diaspora has come to include not only other people but other kinds of experiences, such as minorities, migrants and expatriates. Taking this modern sense, diasporic immigrant literature allows one to go beyond the simplistic view of certain dual oppositions to gasp the complicated, that is, the joint presence of "the same" and "the other", "the local" and "the global", which certainly exerts influence on immigrant families. The 21 st century is the most turbulent and complicated age for human beings. The instantaneous changes of politics between western and eastern world which lasts half an epoch the rising of the third word, the prosperity of national independence movement and the feminism as well as the following economic globalization promote the unprecedented development of diasporic immigrant literature.

\section{Culture Paradox of Diasporic Immigrant}

At the beginning of the twentieth century, America was described as a melting pot and always seen as a special nation consisted of immigrants that are made of majority white immigrants and many other immigrants from different nations. The most famous postmodernist Bhabha even claimed that "the stereotype is a simplification because it is an arrested, fixated form of representation that, in denying the play of difference...constitutes a problem for the representation of the subject in significations of psychic and social relation... The stereotype is not a simplification because it is a false representation of a given reality. "[2] In terms of that, the imposed stereotypes of immigrants is that they are seen as an inferior race and sub-human. Most immigrants always feel uncertain about their own identities and can't sure who they are. They feel confused because they couldn't find their cultural and psychological root of belonging. On one hand, they eager to earn the acceptance of the mainstream society; on the other hand, they can't forget their motherland, and couldn't accept the discrimination from the mainstream socity. 
Facing to the pressure from the cultural assimilation, the immigrants found it difficult to choose between the motherland and the present living country, so the immigrants who live on the margin of American mainstream society, couldn't take an important role in the mainstream but be on the margin of the world. In order to solve this problem, the first generation immigrants and the second generation of immigrants took different ways, but resulted in the same sorrow ending. In Middlesex, by creating a protagonist, who is a split person, the writer probes into the tensile force confronted by the immigrants and their descendants between preservation of original Greek culture and integration into American one. Meanwhile, this novel reflected the struggles that the hero try to keep balance and unity, further to offers a possible special place rather than the betweenness for those postmodernist diaspora in cultural hybridity. In this novel, we should focus on the first generation's attitude towards the pressure from cultural and ethnic assimilation, the second generation's American dream and its ruin, and hermaphrodire's quest for their own identities. In Middlesex, the first generation immigrant try to keep the traditional culture of their motherland, such as their mother language. In the novel, Desdemona, who marries her cousin, so her family identity is fluidity. From the Greek origin of her name, we found that she was fated to fail in her quest for identity both as a diaspora and a new family member. Because of her reluctance to adjust to the new environment in America, she lives a tragic life all her life. Desdemona kept to speak Geek, and refused to learn English, so communication became an obstacle for her, which led to her loneliness in the new world. Since she immigrated to America, Desdemona is trying to fight against assimilationist pressures she couldn't resist. She lived in her own Greek world, even insisted in eating her motherland food. When she is asked to cut down her hair with immigrant culture colour, she is angry at that. another example to show this is when his husband told her that she looks like an American, she is angry and says she doesn't want to be that. She thought that American was not her final destination and she hoped to go back to her motherland. She lived in America just like the fish out of water, that is she seemed as an eternal exile, a visitor for many years, certain little of her adopted country has been sleeping under the locked doors despite her disapproval. But the second generation immigrant Desdemona's son Milton can speak English fluently. Before joining the army, Milton promised his mother he would become literate in Greek, but finally she found that her son even forgot how to speak Greek. Milton grew up in America, so he took the different attitudes towards Greek Orthodox, which draws a dramatic contrast to his mother. He refused to give his child a proper Orthodox baptism is regarded by his mother as a crime with the same bad influence as Turkish atrocities to Greece. All of them are trying to stick on his or her belief, but the most interesting thing is that family members share nothing on this point, which is further emphasized by Milton's proud remarks "That's my girl, pissed on a priest" [3]on Father Mike's partial immersion by Calliope compared with Desdemona's sorry for poor Father Mike.
Different from his parents, Milton living on Seminole is subject to cultural imperialism. Milton's bedroom is furnished in American style, and he is not interested in the past the his family history, his only Greek connection is his love of the minortaur films and Greek myths which he exposes to his child Calliope. The first immigrant generation's experience told us that the history of how the immigrants do when they faced the cultural assimilation. However, the second generation gave up all their tradition from motherland. Despite the two generation chose the different way to live in Ameica, but they cant't solve the problem of their confused identities. Facing to the assimilation, if someone totally refused to accept the new culture, he would isolate and be abandoned by the society; if someone totally gave up his traditional culture, and persists the new culture, he would also found that he lost his root. So the best way for immigrants to live in America is to accept both, that is, do not forget the root when they live in America, which is the third generation, Cal's choice. As immigrants live in America, they should not only keep their native country's culture, but also their country's of residence.

\section{Culture Transcendence of Diasporic Immigrant}

As for the name of the novel, "Middlesex" refers to an ideal way for the immigrants who are also regarded as the margin of the society. Bhabha claims that Hybridity does not mean staying in the middle between the two original things and not to be combinatory and not means to eliminate the differences, but to maintain their own feature and to be something else. Shostak also says "no matter how generous and optimistic Eugenides' novel is, it demonstrates the virtual impossibility of such a third space except as a utopian fantasy"[4]. In Middlesex, the protagonist chose to live as a man, which just like Francisco Collado- Roriguez claims that "inally demands the opening of a borderland or third space where mixed races and intersex identities can coexist", in the process requiring as well "a new type of ethical responsibility, one that openly advocates for a hybrid space of tolerance for individuals and communities"[5]. In Middlesex, the protagonist $\mathrm{Cal}$ is an intersex, that is the combination of male and female. The opposite sides of the contradictory are able to coexist in the same body. This just implies that the traditional culture and the new culture can melt in immigrants, which is the transcendence of immigrant culture. In the novel Cal pursued for his identity all the time. when he is young, his body just like other girls, but when he knows he is a hermaphrodite, he experienced a long period of depression and trauma. Until he met Zola who was also a hermaphrodite, his psychological trauma was cured and he refused to change by surgery, and chose to live as an third gender. As the third generation immigrants, Carl realized that not only his grandmother, who blindly adhere to the traditional culture, but also his father, who blindly accepts American culture can't be succeed. The best way for immigrants is just like Cal's choose about his gender, to be in a inclusive space to change the feeling of non-belonging. At the end of the novel, Cal promises his grandmother that he would go back to his homeland to repair the church which his father did not finish. 
After his father died, Cal says: "And so it was I who, upholding an old Greek custom no one remembered anymore, stay behind on Middlesex, blocking the door, so that Milton's spirit wouldn't reenter the home" [6]. Cal was born in America, but he never forgot his homeland and didn't forget his root.

By describing the margin situation of immigrants, Middlesex reveals that immigrants should jump out of the shackles of the dual system, the preservation of traditional culture and American culture, just like the name of the novel implies that Eugenides tries to probes a new way to offer a possible place rather than the betweenness for the diaspora immigrants in culture hybridity.

\section{References}

[1] William Safran, Diasporas in Modern Societies: Myths of Homeland and Return, 1991, pp. 83-84

[2] Bhabha, Homi. The Location of Culture. London and New York: Routledge, 1994, pp. 107

[3] Eugenides Jeffrey. Middlesex. New York: Picador, 2003, pp. 222

[4] Shostak, Debra. Theory Uncompromised by Practicality: Hybridity in Jeffrey Eugenides'Middlesex. Contemporary Literature 49.3, 2008, pp. 386

[5] Collado-Rodriguez Francisco. Of Self and Country: U.S. Politics, Cultural Hybridity, and Ambivalent Identity in Jeffrey Eugenides's Middlesex.International Fiction Review 33.1-2, 2006, pp.73, 83

[6] Eugenides Jeffrey. Middlesex. New York: Picador, 2003, pp.529 